\title{
FUNGSI INTERMEDIASI PERBANKAN DI DAERAH: PENGUKURAN DAN IDENTIFIKASI FAKTOR-FAKTOR YANG MEMPENGARUHI
}

\author{
Piter Abdullah dan Suseno*
}

\begin{abstract}
The implementation of the Law No 22 and 25 in 1999 has been recognized as starting point for Indonesia in pursuing a comprehensive and ambitious decentralization program. Decentralization in further step has changed many things including people's perception especially on the role of regional banks. For some extend the existing regional banks have been claimed as the main cause for "capital flight" from one region to other regions. LDR is used as the only one parameter for claiming that regional banks do not play its role as the intermediary institution and caused the "capital flight".

This paper, derived from the study of the effectiveness of regional banking conducted by PPSK BI, addressed the issue how regional banking should be assessed and what factors affect its effectiveness as intermediary institution. One of the findings of this study is that LDR should not be used as the only one parameter for the effectiveness of regional banks intermediary function. To assess whether regional bank have played its role effectively or not, this study proposed 3 other parameters: RLCR, TLCR and R2.

Another important finding of this study is that banking decentralization in term of changes from branch office banking into unit office banking will affect positively the intermediation function of regional bank.
\end{abstract}

* Penulis adalah Peneliti pada Pusat Pendidikan dan Studi Kebanksentralan Bank Indonesia. 


\section{PENDAHULUAN}

Implementasi otonomi daerah dan desentralisasi fiskal yang dimulai pada tanggal 1 Januari 2001 telah berjalan lebih dari satu tahun. Dalam periode yang relatif cukup pendek ini sudah cukup untuk melihat beberapa permasalahan mendasar yang timbul dari implementasi otonomi daerah dan desentralisasi fiskal tersebut. Salah satu permasalahan yang dapat dikatakan sebagai permasalahan utama dari penerapan otonomi daerah dan desentralisasi fiskal adalah keterbatasan sumber-sumber pembiayaan pembangunan Keterbatasan ini tidak saja terjadi di daerah-daerah yang tidak memiliki sumber daya alam tetapi juga terjadi di daerah yang kaya akan sumber daya alam. Keterbatasan sumber-sumber pembiayaan pembangunan daerah selain disebabkan oleh belum optimalnya pemerintah daerah untuk menggali semua potensi penerimaan daerah, juga disebabkan oleh ketidakmampuan pemerintah pusat untuk sepenuhnya menjalankan pembagian dana baik dana alokasi umum maupun dana alokasi khusus.

Dengan keterbatasan sumber-sumber penerimaan, maka akan sulit untuk mengharapkan bahwa pemerintah daerah dapat memainkan peranannya sebagai pendorong utama pembangunan di daerah secara optimal. Oleh sebab itu, adalah sangat wajar bila pemerintah daerah pada periode awal otonomi daerah dan desentralisasi fiskal sangat mengharapkan bahwa sektor swasta dapat lebih berperan melaksanakan pembangunan daerah. Dalam kaitan itu maka sumber-sumber pembiayaan bagi sektor swasta menjadi sangat perlu untuk dikembangkan. Salah satu sumber pembiayaan yang utama bagi sektor swasta tersebut adalah perbankan.

Sehubungan dengan peranan perbankan, tuntutan akan tersedianya sumber-sumber pembiayaan pembangunan di daerah telah mendorong pemerintah daerah dan DPRD untuk mempertanyakan kembali efektivitas pelaksanaan fungsi perbankan sebagai lembaga intermediasi. Beberapa pihak berpendapat bahwa perbankan di daerah tidak menjalankan fungsinya sebagai lembaga intermediasi dimana penyaluran kredit jauh lebih kecil bila dibandingkan penghimpunan dana. Hal ini tercermin dari Loan to Deposit Ratio (LDR) perbankan daerah yang sangat kecil.

Lebih lanjut dengan didasarkan kepada rasio penyaluran kredit terhadap penghimpunan dana (LDR), berbagai pihak di daerah meyakini bahwa daerahnya mengalami "capital flight" karena dana yang diserap oleh perbankan di daerah itu tidak disalurkan sebagai kredit untuk pembangunan di daerah yang bersangkutan, melainkan disalurkan sebagai kredit di daerah lain. Di Sumatera Selatan misalnya, loan to deposit ratio (LDR) perbankan daerah yang hanya mencapai kurang lebih 50\% diartikan bahwa dari keseluruhan dana yang dihimpun perbankan di Sumatera selatan sekitar 50\% dilarikan ke luar daerah khususnya ke pulau Jawa. 
Kekhawatiran akan semakin sulitnya sumber pembiayaan pembangunan di daerah kemudian melahirkan berbagai pemikiran untuk mengoptimalkan seluruh resources khususnya sumber dana. Salah satu pemikiran yang berkembang dan dapat dikatakan pemikiran ekstrim adalah pemikiran untuk membatasi aliran dana - termasuk dana perbankan - di daerah. Walaupun pemikiran ini dapat dikatakan ekstrim dan hampir tidak mungkin untuk dilaksanakan, tapi setidaknya pemikiran ini merupakan cerminan bahwa daerah telah menempatkan perbankan sebagai sumber pembiayaan yang sangat vital bagi pembangunan di daerah.

Wacana yang juga berkembang terkait dengan upaya untuk mengoptimalkan sumbersumber dana di suatu daerah, khususnya pasca implementasi UU No. 22 dan No. 25 tahun 1999 tentang otonomi daerah dan perimbangan keuangan pusat dan daerah adalah wacana tentang desentralisasi perbankan. Beberapa pakar ekonomi sempat mengajukan pemikiran bahwa seiring dengan implementasi otonomi daerah maka untuk mendukung pembiayaan pembangunan di daerah perlu adanya perubahan sistem perbankan dari branch banking system yang sifatnya tersentralisasi (centralized) ke unit banking system yang bersifat lebih otonom (decentralized).

Kedua perkembangan pemikiran tersebut diatas sekali lagi menegaskan bahwa daerah telah menempatkan perbankan sebagai sumber pembiayaan yang sangat penting bagi pembangunan di daerah. Oleh karena itu, seluruh permasalahan yang masih menghinggapi perbankan, termasuk tudingan tentang tidak efektifnya fungsi perbankan harus dapat dijawab dengan sebaik-baiknya. Pemahaman semua pihak akan peran perbankan dalam pembangunan daerah akan sangat berguna bagi terciptanya koordinasi yang lebih baik antara perbankan dengan pemerintah dan institusi lainnya di daerah.

Berkaitan dengan upaya mengatasi seluruh permasalahan perbankan di daerah tersebut di atas, dugaan terjadinya "capital flight" di daerah harus dapat dijawab dengan tuntas. Dalam hal ini, harus dapat dibuktikan apakah "capital-flight" tersebut benar-benar terjadi atau mungkin hal itu hanya merupakan fenomena umum yang terjadi secara nasional sehubungan dengan masih berlangsungnya krisis perbankan di Indonesia. Selanjutnya bila "capital flight" itu benar-benar terjadi maka pertanyaan yang kemudian juga harus dijawab adalah faktor-faktor apakah yang menjadi penyebabnya. Apakah "capital flight" tersebut disebabkan ketidak mampuan perbankan mencari peluang usaha yang dapat dibiayai atau lebih disebabkan oleh rendahnya permintaan kredit dari perusahaan-perusahaan di daerah. Di sisi perbankan, faktor lain yang juga masih perlu dibuktikan adalah apakah rendahnya penyaluran kredit tersebut lebih disebabkan oleh minimnya kewenangan kantor-kantor bank di daerah untuk memutus persetujuan kredit. Dengan kata lain perlu dibuktikan apakah kewenangan yang terbatas dari branch banking system yang dianut oleh perbankan nasional menyebabkan terhambatnya penyaluran kredit di daerah. 


\section{TINJAUAN PERBANKAN DI INDONESIA PASCA KRISIS}

\section{Methodologi}

Upaya penyehatan terhadap sistem perbankan yang dilakukan pasca krisis sebagaimana diuraikan diatas telah menyebabkan perubahan struktur perbankan di Indonesia. Untuk melihat secara lebih mendalam perubahan yang terjadi pada sistem perbankan di Indonesia paska krisis pada sub bab ini akan dilakukan analisa perubahan struktur perbankan dengan mempergunakan shift and share analysis.

Shift and share analysis merupakan satu alat analisa yang biasanya dipergunakan untuk menjelaskan faktor-faktor yang menyebabkan pertumbuhan suatu daerah tertentu dengan memperbandingkan pertumbuhan daerah tersebut dengan pertumbuhan nasional. Alat analisa ini membedakan pertumbuhan daerah menjadi 3 komponen pertumbuhan yaitu: komponen pertumbuhan yang merupakan kontribusi daerah terhadap pertumbuhan nasional (region's share of national growth), komponen pertumbuhan yang disebabkan oleh perbedaan komposisi industri antara daerah dan nasional (the industry mix shift component), dan komponen pertumbuhan yang disebabkan oleh perbedaan competitive advantage dari suatu daerah dibandingkan nasional (competitive shift component).

Dengan berdasarkan penggunaannya pada analisa pertumbuhan daerah sebagaimana dijelaskan di atas pada paper ini shift and share analysis akan dikembangkan sehingga dapat menjelaskan kelompok bank mana saja yang menguasai perbankan nasional dan faktor-faktor apakah yang secara dominan menyebabkan pertumbuhan perbankan di Indonesia pasca krisis. Dalam hal ini analisa dilakukan dengan memperbandingkan pertumbuhan suatu kelompok bank terhadap pertumbuhan perbankan nasional sebelum dan sesudah krisis. Pertumbuhan perbankan diukur dengan mempergunakan pertumbuhan asset bank sebagaiman dicerminkan oleh perkembangan pos-pos pada neraca bank.

Selanjutnya pertumbuhan perbankan akan dibedakan menjadi 3 komponen yaitu: komponen pertumbuhan yang merupakan kontribusi suatu kelompok bank terhadap pertumbuhan perbankan nasional (group's share of national growth), komponen pertumbuhan yang disebabkan oleh perbedaan komposisi pos-pos neraca antara kelompok bank dengan perbankan nasional (the balance sheet mix shift component), dan komponen pertumbuhan yang disebabkan oleh perbedaan competitive advantage dari suatu kelompok bank dibandingkan perbankan nasional secara keseluruhan (competitive shift component).

Komponen pertumbuhan kelompok bank atau group's share of national growth (GS) dihitung dengan rumus sebagai berikut:

$$
\mathrm{GS}_{\mathrm{i}}=\mathrm{e}_{\mathrm{i}}{ }^{*}\left(\mathrm{DE} \mathrm{E}_{\mathrm{N}} / \mathrm{E}_{\mathrm{N}}\right)
$$


Dimana,

$\mathrm{e}_{\mathrm{i}} \quad=$ Asset/Kekayaan kelompok bank pada pos neraca i di awal periode.

$\mathrm{E}_{\mathrm{N}}=$ Total Asset/kekayaan perbankan nasional di awal periode.

$\mathrm{DE}_{\mathrm{N}}=$ Perubahan Total Asset/kekayaan perbankan nasional

Sementara itu komponen pertumbuhan komposisi pos-pos neraca atau the balance sheet mix shift component (BMS) dihitung dengan rumus sebagai berikut:

$$
B M S_{i}=e_{i}^{*}\left(D E_{i} / E_{i}-D E_{N} / E_{N}\right)
$$

Dimana,

$\mathrm{e}_{\mathrm{i}}=$ Asset/Kekayaan kelompok bank pada pos neraca i di awal periode.

$\mathrm{E}_{\mathrm{i}}=$ Asset/kekayaan perbankan nasional pada pos neraca i di awal periode.

$\mathrm{DE}_{\mathrm{i}}=$ Perubahan Asset/kekayaan perbankan nasional pada pos neraca i.

$\mathrm{E}_{\mathrm{N}}=$ Total Asset/kekayaan perbankan nasional pada awal periode.

$\mathrm{DE}_{\mathrm{N}}=$ Perubahan Total Asset/kekayaan perbankan nasional

Untuk menghitung komponen pertumbuhan ke tiga yaitu pertumbuhan yang disebabkan oleh perbedaan competitive advantage atau competitive shift component (CS) rumus yang dipergunakan adalah:

$$
C S_{i}=e_{i}^{*}\left(D e_{i} / e_{i}-D E_{i} / E_{i}\right)
$$

Dimana,

$\mathrm{e}_{\mathrm{i}}=$ Asset/Kekayaan kelompok bank pada pos neraca i di awal periode.

$\mathrm{De}_{\mathrm{i}}=$ Perubahan Asset/Kekayaan kelompok bank pada pos neraca i di awal periode.

$\mathrm{E}_{\mathrm{i}}=$ Asset/kekayaan perbankan nasional pada pos neraca i di awal periode.

$\mathrm{DE}_{\mathrm{i}}=$ Perubahan Asset/kekayaan perbankan nasional pada pos neraca $\mathrm{i}$.

$\mathrm{E}_{\mathrm{N}}=$ Total Asset/kekayaan perbankan nasional pada awal periode.

$\mathrm{DE}_{\mathrm{N}}=$ Perubahan Total Asset/kekayaan perbankan nasional

Berdasarkan ketiga rumus di atas, maka perubahan asset/kekayaan suatu pos neraca ((pos neraca i) dari suatu kelompok bank selanjutnya dapat diperhitungkan sebagai:

$$
\begin{aligned}
D e_{i} & =G S_{i}+B M S_{i}+C S_{i} \\
& =e_{i}^{*}\left(D E_{N} / E_{N}\right)+e_{i}^{*}\left(D E_{i} / E_{i}-D E_{N} / E_{N}\right)+e_{i}^{*}\left(D e_{i} / e_{i}-D E_{i} / E_{i}\right)
\end{aligned}
$$

Dengan demikian total pertumbuhan asset/kekayaan dari suatu kelompok bank adalah:

$$
\begin{aligned}
& { }_{i=1} \stackrel{a}{a}^{n} D e_{i}={ }_{i=1} \stackrel{a}{a}^{n}\left(G_{i}+B M S_{i}+C S_{i}\right) \\
& ={ }_{i=1} \stackrel{a}{n}^{n} e_{i}^{*}\left(D E_{N} / E_{N}\right)+{ }_{i=1} \stackrel{a}{ }^{n} e_{i}^{*}\left(D E_{i} / E_{i}-D E_{N} / E_{N}\right)
\end{aligned}
$$




$$
+{ }_{i=1} \stackrel{̊}{n}^{n} e_{i}^{*}\left(D e_{i} / e_{i}-D E_{i} / E_{i}\right)
$$

dimana, $\mathrm{n}$ adalah jumlah pos-pos neraca yang terdapat pada Neraca Bank.

\section{Data}

Dalam rangka melakukan analisa perubahan struktur perbankan dengan menggunakan shift and share analysis sebagaimana dijelaskan di atas, perbankan nasional dikelompokkan menjadi 6 kelompok besar yaitu: kelompok bank pemerintah, kelompok bank swasta nasional rekap, kelompok bank swasta nasional devisa non rekap, kelompok bank swasta nasional non devisa non rekap, kelompok bank asing dan campuran dan terakhir kelompok bank lainnya.

Data yang dipergunakan dalam pengukuran perubahan atau pertumbuhan asset/ kekayaan perbankan adalah data neraca kosolidasi per kelompok bank periode Desember 1996 (sebelum krisis) dan periode Desember 2001 (pasca krisis). Daftar bank pada masingmasing kelompok bank serta keseluruhan perhitungan dekomposisi pertumbuhan bank yang dipergunakan pada paper ini dapat dilihat pada lampiran.

\section{Hasil Analisa}

Hasil perhitungan dekomposisi pertumbuhan perbankan nasional selama periode 1996-2001 terlihat pada table 2.1.

Tabel 2.1.

Shift and Share Analysis Pertumbuhan Perbankan Indonesia Periode 1996 - 2001 (Dalam Milyar Rupiah)

\begin{tabular}{|c|c|c|c|c|c|}
\hline Kelompok Bank & $\begin{array}{l}\text { Total } \\
\text { Growth } \\
\text { (A) }\end{array}$ & $\begin{array}{c}\text { Groups } \\
\text { Share } \\
\text { (B) }\end{array}$ & $\begin{array}{l}\text { Total shift } \\
\begin{array}{l}\text { (C) }=(A)-(B) \\
=(D)+(E)\end{array}\end{array}$ & $\begin{array}{c}\text { Balance } \\
\text { Sheet Mix } \\
\text { Shift } \\
\text { (D) }\end{array}$ & $\begin{array}{c}\text { Competitive } \\
\text { Shift } \\
\text { (E) }\end{array}$ \\
\hline Bank Pemerintah & 435,669 & 114,482 & 321,187 & 226,135 & 95,052 \\
\hline $\begin{array}{l}\text { Bank Swasta Rekap } \\
\text { Bank Swasta Devisa }\end{array}$ & 141,706 & 150,689 & $-8,983$ & 160,008 & $-168,991$ \\
\hline $\begin{array}{l}\text { Non Rekap } \\
\text { Bank Swasta Non Devisa }\end{array}$ & 51,791 & 8,986 & 42,805 & 8,361 & 34,443 \\
\hline Non Rekap & 5,267 & 2,352 & 2,916 & 1,707 & 1,209 \\
\hline Bank Asing dan Campuran & 93,009 & 48,632 & 44,378 & $-29,947$ & 74,325 \\
\hline Bank Lainnya & $-138,083$ & 264,219 & $-402,302$ & $-366,264$ & $-36,038$ \\
\hline Total & 589,360 & 589,360 & 0 & 0 & 0 \\
\hline
\end{tabular}

Sumber: Hasil Analisa berdasarkan data konsolidasi LBU bank-bank periode 1996 dan 2001 
Seperti terlihat pada tabel 2.1, diketahui bahwa struktur perbankan Indonesia pasca krisis mengalami pertumbuhan yang didominasi oleh kelompok bank pemerintah dan kelompok bank swasta rekap. Pertumbuhan dari bank-bank pemerintah dipengaruhi terutama oleh struktur neraca dan kemampuan daya saing. Untuk struktur neraca, keberadaan obligasi pemerintah merupakan faktor yang dominan. Sementara itu keunggulan daya saing yang ditunjukkan terutama oleh pertumbuhan dana pihak ke III (DPK) pada kelompok bank pemerintah lebih disebabkan oleh beralihnya kepercayaan masyarakat dari beberapa bank swasta ke bank-bank milik pemerintah.

Pertumbuhan asset perbankan yang lebih banyak disebabkan oleh keberadaan obligasi rekap menunjukkan bahwa pertumbuhan tersebut harus disikapi secara hati-hati terutama mengingat obligasi rekap merupakan asset perbankan yang bersifat semu. Meskipun secara nominal selama periode 1996 sampai dengan 2001 perbankan mengalami pertumbuhan asset yang cukup besar, tetapi hal tersebut tidak dapat diartikan sebagai pertumbuhan yang riil. Untuk dapat menyatakan pertumbuhan perbankan nasional secara riil maka obilgasi rekap harus dikeluarkan terlebih dahulu dari portopolio perbankan.

\section{PENGUKURAN KINERJA PERBANKAN DI DAERAH}

\section{Alat Ukur Kinerja Perbankan di Daerah}

Alat ukur utama yang selama ini dipergunakan untuk mengukur kinerja perbankan khususnya berkenaan dengan pelaksanaan fungsi intermediasi adalah loan to deposit ratio (LDR), yaitu perbandingan atau ratio antara dana pihak ke III (DPK) yang berhasil dihimpun oleh perbankan (pelaksanaan fungsi intermediasi penghimpunan dana) terhadap penyaluran dana dalam bentuk kredit (pelaksanaan fungsi penyaluran dana). Dilihat dari komponen pembentuknya LDR merupakan suatu ukuran ideal yang dapat dipergunakan untuk mengukur kinerja perbankan sebagai lembaga intermediasi. Namun demikian apakah LDR senantiasa tepat untuk dipergunakan sebagai alat ukur kinerja perbankan termasuk pada kondisi perbankan pasca krisis?

Sebagaimana telah dijelaskan sebelumnya, perbankan di Indonesia mengalami perubahan struktur yang cukup signifikan. Perubahan ini juga terjadi dalam hal pelaksanaan fungsi intermediasi yang dicerminkan oleh penghimpunan dana dan penyaluran kredit. Gambar berikut menunjukkan hal tersebut.

Pada gambar 3.1 terlihat bahwa pertumbuhan kredit menurun secara tajam mulai dari awal tahun 1998 sampai dengan pertengahan tahun 1999, saat dimana kredit mengalami penurunan sebesar lebih dari 50\%. Di sisi lain, pertumbuhan DPK juga mengalami penurunan walaupun tidak secara tajam dan mulai stabil sejak tahun 1999 (di saat DPK 


\section{Gambar 3.1}

Dana dan Kredit Perbankan, Tahun 1994 - 2002

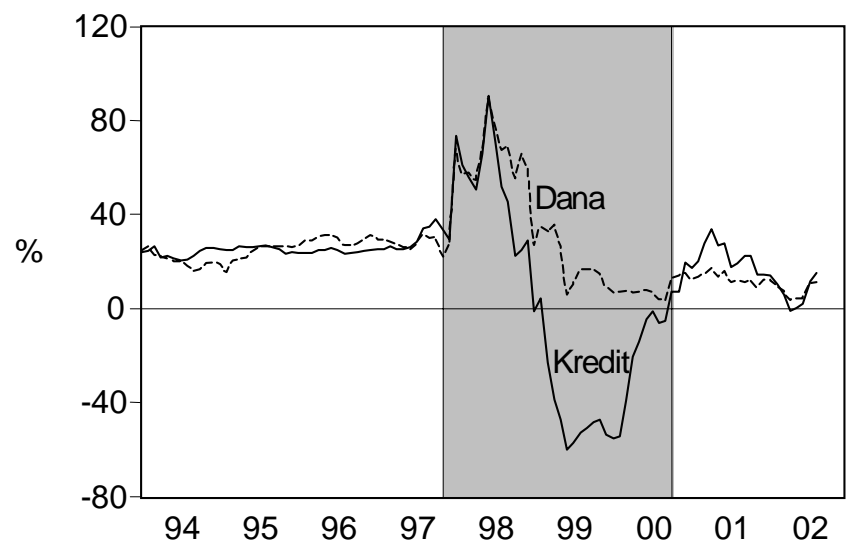

mengalami pertumbuhan negatif yang terbesar). Kondisi ini selanjutnya menyebabkan gap yang sangat besar antara pertumbuhan DPK dan pertumbuhan Kredit. Sejak triwulan I tahun 2000, pertumbuhan kredit mulai membaik dan menjadi positif pada triwulan III tahun yang sama. Setelah itu, pertumbuhan kredit telah melampaui pertumbuhan DPK dan keduanya bergerak stabil sampai dengan tahun 2002.

Pertumbuhan positif yang stabil dan seimbang antara DPK dan Kredit mulai awal tahun 2000 sampai dengan saat ini menunjukkan bahwa secara umum kondisi perbankan telah menunjukkan perbaikan yang signifikan. Dapat dikatakan bahwa kondisi perbankan telah mulai kembali normal. Kesimpulan ini jauh berbeda dengan kesimpulan sebelumnya yang didasarkan kepada angka LDR semata yang menyebutkan bahwa kondisi perbankan masih jauh dari normal sebagaimana yang diharapkan.

Menimbang bahwa penggunaan LDR semata tanpa penggunaan alternatif ukuran kinerja perbankan lainnya dapat menimbulkan penafsiran yang keliru atas kondisi perbankan, maka dalam rangka pengukuran kinerja perbankan khususnya perbankan di daerah pada paper ini LDR akan dilengkapi dengan beberapa alat ukur alternatif lain yaitu:

1. Total Loan to Lending Capacity (TLCR)

2. Real Loan to Lending Capacity (RLCR)

3. Angka korelasi penyaluran kredit dan DPK (R2).

Lending Capacity dimaksudkan sebagai ukuran kemampuan sebenarnya dari perbankan untuk menyalurkan kredit. Penggunaan ukuran ini didasarkan kepada fakta bahwa tidak semua dana yang diserap oleh perbankan dapat disalurkan dalam bentuk kredit. Sementara itu Total Loan dimaksudkan sebagai total realisasi kredit yang disalurkan 
oleh perbankan di daerah termasuk kredit yang telah dihapusbukukan. Alasan memasukkan kembali kredit yang telah dihapusbukukan adalah bahwa meskipun kredit tersebut telah dihapusbukukan ia tetap merupakan wujud dari pelaksanaan fungsi perbankan yaitu menyalurkan kredit. Terakhir, Real Loan dimaksudkan sebagai jumlah keseluruhan kredit yang diterima oleh daerah baik dari perbankan setempat maupun dari perbankan di luar daerahnya.

Tabel 3.1.

Simulasi perhitungan LDR, TLCR, dan RLCR

\begin{tabular}{|c|c|c|}
\hline No. & $\begin{array}{l}\text { KAPASITAS PERBANKAN } \\
\text { Dana Pihak Ke III }\end{array}$ & $\begin{array}{l}\text { Contoh Data } \\
\text { ( Rp. Milyar) }\end{array}$ \\
\hline 1 & Giro & 402.9 \\
\hline 2 & Giro KPKN (pengurang)* & 155.4 \\
\hline 3 & Potensi Giro (1-2) & 247.5 \\
\hline 4 & Rata-rata pengendapan Giro ${ }^{* *}$ & $10 \%$ \\
\hline 5 & Potensi riil dari Giro $(3 \times 4)$ & 24.75 \\
\hline 6 & Tabungan & 986.7 \\
\hline 7 & Rata-rata pengendapan tabungan** & $80 \%$ \\
\hline 8 & Potensi riil dari Tabungan $(6 \times 7)$ & 789.36 \\
\hline 9 & Deposito & 767.2 \\
\hline 10 & Total DPK $(1+6+9)$ & 2156.8 \\
\hline 11 & Total potensi dana pihak ke III $(5+8+9)$ & 1581.31 \\
\hline 12 & Share GWM (5\% dari DPK) & 107.84 \\
\hline 13 & Kemampuan riil Bank memberikan kredit (11-12) & 1473.47 \\
\hline \multicolumn{3}{|c|}{ REALISASI KREDIT } \\
\hline 14 & Kredit yang disalurkan oleh perbankan daerah & 857 \\
\hline 15 & Kredit yang dihapusbukukan (ekstrakomtable) & 168.1 \\
\hline 16 & Total kredit yang disalurkan oleh perbankan daerah $(14+15)$ & 1025.1 \\
\hline 17 & $\begin{array}{l}\text { Kredit yang diterima dunia usaha daerah dari bank diluar } \\
\text { daerah (kredit berdasarkan lokasi) }\end{array}$ & 371.3 \\
\hline 18 & Total Kredit yang diterima dunia usaha di daerah $(16+17)$ & 1396.4 \\
\hline \multicolumn{3}{|c|}{ PERHITUNGAN LDR, TLCR, DAN RLCR } \\
\hline 19 & Loan to deposit ratio / LDR $\left(14 / 10^{*} 100\right)$ & $39.73 \%$ \\
\hline 20 & Real Loan to Lending Capacity Ratio / RLCR (16/13*100) & $69.57 \%$ \\
\hline 21 & Total Loan to Lending Capacity Ratio / TLCR $\left(18 / 13^{*} 100\right)$ & $94.77 \%$ \\
\hline
\end{tabular}

Catatan:

- Giro KPKN untuk keperluan pembayaran gaji/non gaji yang tidak dapat ditanamkan dalam kredit karena perputarannya yang sangat cepat.

- Data rata-rata pengendapan giro dan tabungan diketahui dari masing-masing Kantor Cabang Bank. 
Dalam hal perhitungan kemampuan riil dari perbankan untuk memberikan kredit, paper ini akan didasarkan kepada konsep bahwa kemampuan tersebut hanya dapat diperoleh dari sisi passiva neraca bank, yaitu dari Dana Pihak ke III dan Modal bank. Sementara sebagaimana diketahui untuk kantor cabang bank di daerah, modal bank tidak dapat diperhitungkan sebagai sumber kemampuan memberi kredit. Dengan demikian kemampuan bank di daerah untuk memberikan kredit hanya didasarkan pada Dana Pihak ke III (DPK), dan dengan memperhitungkan pula hal-hal yang menjadi pengurang antara lain yaitu: kebutuhan likuiditas operasional perbankan sehari-hari yang antara lain dipengaruhi oleh karakteristik dana pihak ke III serta Share GWM.

Sementara itu untuk pengukuran realisasi pemberian kredit, data yang dipergunakan dalam paper ini adalah: posisi pemberian kredit perbankan di daerah, besarnya akumulasi kredit yang telah dihapusbukukan, dan posisi kredit yang diterima oleh dunia usaha di daerah secara keseluruhan (besarnya kredit berdasarkan lokasi).

Dengan mempertimbangkan kemampuan riil (lending capacity) perbankan dan realisasi pemberian kredit di atas, maka perhitungan LDR, TLCR, dan RLCR dapat dilakukan sebagaimana terlihat pada simulasi berikut ini (Tabel 3.1).

\section{Data}

Cakupan penelitian khususnya dalam hal pengukuran pelaksanaan fungsi intermediasi perbankan di daerah adalah meliputi semua provinsi di Indonesia sebelum pemekaran wilayah di luar Provinsi DKI Jakarta yaitu 25 provinsi. Data yang dipergunakan merupakan gabungan antara data sekunder dan primer yang meliputi. Data sekunder adalah data statistik perbankan yang berasal dari laporan bulanan bank-bank yang dimiliki oleh KBI (data SEKDA). Sementara rata-rata pengendapan giro dan tabungan merupakan data primer yang didapatkan dari masing-masing kantor cabang di daerah dengan rumus perhitungan sebagai berikut:

$X=100 \%-\left((T-S) / D^{*} 100 \%\right)$

Dimana:

$\mathrm{X}=$ Rata-rata pengendapan Giro atau Tabungan.

$\mathrm{T}=$ Rata-rata penarikan Giro atau Tabungan setiap hari

$\mathrm{S} \quad=$ Rata-rata penyetoran Giro/tabungan setiap hari.

$\mathrm{D} \quad=$ Rata-rata saldo harian giro/tabungan

Rata-rata pengendapan giro dan tabungan didasarkan kepada data bulan April 2002 yang kemudian diasumsikan sama untuk semua bulan pada periode tahun 2001 dan 2002. 
Dari 25 provinsi yang menjadi daerah paper terdapat daerah-daerah yang tidak memiliki data lengkap. Data yang tidak tersedia tersebut meliputi data pengendapan giro dan tabungan, data jumlah kredit yang dihapusbukukan dan data jumlah kredit yang diberikan oleh perbankan didaerah. Untuk daerah yang tidak memiliki data pengendapan giro dan tabungan dilakukan proxi dengan mengasumsikan bahwa pengendapan giro dan tabungan di daerah-daerah tersebut adalah sebesar $100 \%$. Sementara untuk tidak adanya data jumlah kredit yang dihapusbukukan didekati dengan menganggap tidak ada kredit yang dihapusbukukan (nihil). Terakhir untuk jumlah kredit yang diberikan oleh perbankan di daerah diasumsikan bahwa total kredit yang diberikan (termasuk dari luar daerah) sebagai kredit yang diberikan oleh perbankan di daerah tersebut.

\section{Hasil Pengukuran dan Analisa}

Hasil pengukuran pelaksanaan fungsi intermediasi perbankan secara keseluruhan untuk 25 daerah provinsi terangkum di dalam table 3.2 di bawah ini.

\section{Tabel 3.2}

Pengukuran Kinerja Penyaluran Kredit Perbankan Daerah

Di 25 Propinsi Periode Tahun 2001.

\begin{tabular}{|c|c|c|c|c|c|}
\hline No. & Propinsi & LDR & RCLR & TCLR & $\mathbf{R} 2$ \\
\hline 1 & Nangro Aceh Darussalam & 60.58 & 60.58 & 63.77 & 0.10 \\
\hline 2 & Sumatera Utara & 64.23 & 86.15 & 86.15 & 0.76 \\
\hline 3 & Sumatera Barat & 59.10 & 77.41 & 69.96 & 0.93 \\
\hline 4 & Riau & 61.84 & 111.29 & 67.56 & 0.35 \\
\hline 5 & Jambi & 38.52 & 83.08 & 40.14 & 0.95 \\
\hline 6 & Sumatera Selatan & 56.61 & 64.16 & 64.16 & 0.77 \\
\hline 7 & Bengkulu & 54.13 & 77.58 & 68.96 & 0.65 \\
\hline 8 & Lampung & 39.30 & 60.83 & 43.92 & 0.92 \\
\hline 9 & Jawa Barat & 32.81 & 104.76 & 46.01 & 0.16 \\
\hline 10 & Jawa Tengah & 41.68 & 100.97 & 51.54 & 0.94 \\
\hline 11 & DI Yogyakarta & 22.77 & 25.70 & 25.70 & 0.95 \\
\hline 12 & Jawa Timur & 29.44 & 32.92 & 32.92 & 0.84 \\
\hline 13 & Bali & 38.30 & 54.16 & 47.58 & 0.95 \\
\hline 14 & Nusa Tenggara Barat & 66.21 & 78.92 & 78.92 & 0.93 \\
\hline 15 & Nusa Tenggara Timur & 33.99 & 36.69 & 35.95 & 0.94 \\
\hline 16 & Kalimanta Barat & 33.94 & 73.54 & 54.59 & 0.71 \\
\hline 17 & Kalimantan Tengah & 35.35 & 65.02 & 44.26 & 0.76 \\
\hline 18 & Kalimantan Selatan & 69.13 & 98.59 & 76.66 & 0.84 \\
\hline 19 & Kalimantan Timur & 28.29 & 117.08 & 53.39 & 0.42 \\
\hline 20 & Sulawesi Utara & 42.71 & 91.89 & 73.61 & 0.65 \\
\hline 21 & Sulawesi Tengah & 40.86 & 64.98 & 52.65 & 0.94 \\
\hline 22 & Sulawesi Selatan & 54.15 & 65.50 & 65.50 & 0.66 \\
\hline 23 & Sulawesi Tenggara & 40.86 & 65.00 & 52.66 & 0.94 \\
\hline 24 & Maluku & 13.80 & 30.35 & 30.35 & 0.43 \\
\hline 25 & Irian Jaya & 22.13 & 24.04 & 24.04 & -0.17 \\
\hline
\end{tabular}

Sumber: Hasil perhitungan berdasarkan data LBU bank bank periode tahun 2001. 
Hasil Pengukuran LDR, RLCR, TLCR dan R2 sebagaimana terlihat pada tabel 3.2. menunjukkan bahwa:

a. Berdasarkan LDR, perbankan di daerah selama periode tahun 2001 pada umumnya belum menjalankan fungsi intermediasi secara effektif. Daerah-daerah yang dapat dikatakan perbankannya telah menjalankan fungsi intermediasi dengan cukup baik dalam pengertian memiliki LDR cukup tinggi hanya meliputi 5 daerah provinsi yaitu Kalimantan Selatan, Nusa Tenggara Barat, Sumatera Utara, Riau dan Nanggroe Aceh Darussalam (rata-rata LDR diatas 60\%).

b. Sementara itu daerah-daerah yang memiliki rasio penyaluran kredit RLCR diatas $60 \%$ meliputi 11 daerah provinsi. Hal ini berarti bahwa bila diukur berdasarkan kapasitasnya untuk menyalurkan kredit maka perbankan daerah yang dapat dikatakan melaksanakan fungsi intermediasi dengan cukup baik tidak hanya terjadi di 6 provinsi tetapi 11 provinsi. Hasil lain dari pengukuran RLCR adalah bahwa perbankan di daerah secara umum telah menjalankan fungsinya relatif lebih baik dibandingkan apabila hanya didasarkan LDR. Hal ini lebih ditegaskan lagi dengan penggunaan R2, dimana diketahui bahwa perbankan di daerah secara umum telah berupaya meningkatkan penyaluran kreditnya searah dengan peningkatan DPK.

c. Penggunaan TLCR di sisi lain mengungkapkan fakta adanya daerah-daerah yang memiliki LDR yang relatif rendah tetapi secara riil mengalami capital inflow. Daerahdaerah tersebut adalah Kalimantan Timur, Riau dan Jawa Barat. Rata-rata LDR perbankan di Kalimantan Timur selama tahun 2001 adalah 28, 29\% yang berarti hanya $28,29 \%$ dari total dana yang dihimpun oleh perbankan yang disalurkan sebagai kredit. Sisanya ditanamkan dalam bentuk lain, terutama ditempatkan ke kantor pusat dalam bentuk rekening antar kantor. Sementara angka TLCR untuk perbankan di Kalimantan Timur adalah $117 \%$ yang berarti nilai riil kredit perbankan yang diterima oleh dunia usaha di Kalimantan Timur jauh lebih besar dibandingkan kapasitas pemberian kredit yang dimiliki perbankan di daerah tersebut, sekaligus berarti Kalimantan Timur secara total menerima aliran dana masuk. Fakta ini menunjukkan bahwa LDR yang rendah tidak dapat menjadi justifikasi terjadinya "capital flight".

d. Secara umum angka TLCR untuk semua daerah provinsi di Indonesia selama periode tahun 2001 adalah jauh lebih besar dibandingkan RLCR. Dengan mengasumsikan bahwa TLCR menggambarkan potensi yang dimiliki oleh suatu daerah sementara RLCR merupakan realisasi dari kapasitas yang ada maka dapat disimpulkan bahwa potensi yang dimiliki oleh daerah-daerah tersebut tidak termanfaatkan sepenuhnya. Hal ini terkait erat dengan iklim investasi di daerah yang tidak kondusif yang menyebabkan perusahaan daerah tidak dapat berkembang baik atau menyebabkan perusahaan daerah 
yang sudah berkembang memindahkan kantor pusatnya ke Jakarta. Seiring dengan adanya otonomi daerah, maka iklim investasi di daerah harus dapat diperbaiki. Hanya dengan jalan itulah seluruh potensi yang ada di daerah dapat dimanfaatkan secara penuh yang pada gilirannya akan mendorong pertumbuhan penyaluran kredit di daerah.

\section{IDENTIFIKASI FAKTOR-FAKTOR YANG MEMPENGARUHI PENYALURAN KREDIT DI DAERAH}

\section{Hipotesa}

2 faktor utama dalam paper ini yang diduga memiliki pengaruh yang cukup significant terhadap penyaluran kredit adalah faktor kewenangan bank untuk memutus pemberian kredit dan faktor keberadaan alternatif penanaman dana selain kredit. Kedua faktor ini kemudian dikembangkan menjadi dua pertanyaan sebagai berikut:

1. Seberapa jauh keterbatasan kewenangan memutus pemberian kredit yang ada di kantor cabang mempengaruhi kelancaran penyaluran kredit di daerah, dan apakah peningkatan kewenangan bagi kantor cabang bank akan dapat meningkatkan kinerja penyaluran kredit perbankan di daerah.

2. Seberapa jauh persoalan keuangan perbankan seperti NPLs mempengaruhi keputusan penyaluran kredit dan apakah penanaman dana non kredit seperti surat berharga mempengaruhi volume penyaluran kredit di daerah.

Pertanyaan pertama selain ditujukan untuk mengidentifikasi faktor-faktor yang mempengaruhi penyaluran kredit perbankan di daerah (sebagai indikator efektivitas fungsi intermediasi perbankan), ditujukan pula untuk melihat dampak yang mungkin terjadi apabila desentralisasi perbankan diterapkan pada sistem perbankan di Indonesia. Untuk itu analisa akan difokuskan pada peranan kedua sistem tersebut dalam meningkatkan fungsi intermediasi perbankan di daerah.

Sesuai focus paper yang dikembangkan di atas, unit banking system akan diwakili oleh kantor-kantor cabang bank yang memiliki kewenangan yang besar sementara branch banking system akan diwakili oleh kantor-kantor cabang bank dengan kewenangan yang rendah atau bahkan tidak memiliki kewenangan sama sekali. Analisa dilakukan dengan memperbandingkan rata-rata prosentasi persetujuan penyaluran kredit dan lama waktu proses persetujuan kredit yang diberikan oleh masing-masing kelompok bank.

Pertanyaan kedua ditujukan untuk menganalisa hubungan kantor pusat dan kantor cabang serta untuk mengkonfirmasi keberadaan bentuk-bentuk alternatif penanaman dana yang dimiliki oleh bank dan seberapa besar pengaruhnya kepada penyaluran kredit (fungsi 
intermediasi perbankan). Analisa hubungan kantor pusat dan kantor cabang ditujukan untuk membuktikan hipotesa bahwa memburuknya kondisi perbankan semata-mata terjadi di kantor pusat bank yang sekaligus juga mempertegas argumen perlunya perubahan dari branch banking system ke unit banking system. Dasar pemikiran argumen ini adalah bahwa bila terbukti permasalahan bank sesungguhnya hanya terjadi di kantor pusat maka dengan unit banking system permasalahan tersebut tidak akan mempengaruhi kinerja perbankan di daerah karena pada sistem ini manajemen bank antara kantor pusat bank dan kantor cabang dapat dikatakan terpisah.

Sementara itu analisa keberadaan bentuk-bentuk alternatif penanaman dana terkait dengan hipotesa bahwa pada masa setelah krisis perbankan mengurangi penyaluran kredit dengan tujuan meminimumkan risiko sekaligus mempertahankan CAR perbankan pada level tertentu (diatas $8 \%$ ). Analisa dilakukan dengan melihat komposisi penanaman dana, tingkat risiko masing-masing alternatif, dan persepsi para pengelola bank.

\section{Model Analisa}

Untuk menjawab berbagai pertanyaan diatas, model analisa yang dikembangkan dalam paper ini adalah sebagai berikut:

1. Model pembuktian pengaruh wewenang Kantor Cabang Bank terhadap penyaluran kredit perbankan di daerah.

Pembuktian pengaruh wewenang Kantor Cabang Bank terhadap penyaluran kredit dilakukan dengan menganalisa efek dari kewenangan yang dimiliki KC Bank untuk menyalurkan kredit terhadap proses persetujuan kredit yang diberikan oleh bank pada setiap jenis kredit, yaitu kredit investasi, kredit modal kerja, kredit konsumsi, dan kredit lainnya. Sebagai ukuran kelancaran penyaluran kredit oleh bank, pada paper ini dipergunakan data prosentase persetujuan kredit, yaitu perbandingan antara nilai nominal kredit yang disetujui terhadap nilai nominal kredit yang diajukan oleh nasabah bank.

Sementara itu sebagai treatments kewenangan maka pada paper ini dilakukan pengelompokkan berdasarkan ada tidaknya atau besar kecilnya kewenangan yang dimiliki oleh KC Bank untuk memutus penyaluran kredit. Untuk itu, kantor-kantor cabang bank dikelompokkan menjadi 5 sebagai berikut:

1. KCB dengan wewenang kredit $>$ Rp. 1 milyar

2. KCB dengan wewenang kredit s.d Rp. 1 milyar

3. KCB dengan wewenang kredit s.d Rp. 500 juta

4. KCB dengan wewenang kredit s.d Rp. 100 juta 
5. KCB yang tidak memiliki kewenangan memutus kredit.

Hipotesa dasar yang dikembangkan dalam analisa pengaruh kewenangan ini adalah bahwa bila perbedaan kewenangan tidak memiliki penyaruh yang nyata maka tingkat rata-rata prosentase persetujuan kredit dari masing-masing kelompok kantor cabang bank di atas akan relatif sama atau tidak ada perbedaan secara significant.

Sesuai hipotesis diatas, pengujian statistik yang dilakukan adalah untuk mengetahui apakah rata-rata prosentase persetujuan kredit dari setiap kelompok bank pada setiap jenis kredit memiliki perbedaan yang significant. Karena rata-rata prosentase persetujuan kredit yang akan diuji adalah untuk seluruh jenis kredit (lebih dari satu) maka metode statistik yang umum dapat dipergunakan adalah General Linear Model Multivariat atau Manova. Disebut multivariate karena variabel yang akan dianalisa (dependent variabels) adalah lebih dari satu,

Sesuai hipotesa dasar diatas, model MANOVA yang dipergunakan dirumuskan sebagai berikut:

$$
\mathrm{y}_{i \mathrm{~m} j}=\mathrm{m}+\mathrm{a}_{i m}+\mathrm{e}_{i m j}
$$

\section{Dimana}

$i=$ No. urut treatments $=1,2,3, \ldots ., \mathrm{k}$

$m=$ No urut dependent variabels $=1,2, \ldots, 1$

$j=$ No urut pengamatan $=1,2, \ldots, \mathrm{n}$

$\mathrm{k}=$ jumlah treatments $=5$

$1=$ jumlah dependent variabels $=4$

$\mathrm{n}_{i}=$ jumlah observasi dg treatment $i$.

$\mathrm{y}_{i m j}=$ Prosentase nilai nominal persetujuan kredit untuk jenis kredit ke m pada treatment ke $i$, nomor pengamatan kej.

$\mathrm{m}$ = nilai rata-rata observasi dependent variabel (pada setiap treatment)

$\mathrm{a}_{i m}=$ efek pada dependent variabel $\mathrm{m}$ yang diakibatkan oleh treatment ke $i$, dimana ${ }_{i=1} \mathrm{~S}^{\mathrm{k}} \mathrm{a}_{i m}=0$

$\mathrm{e}_{i j m}=$ random error

Selanjutnya, uji hipotesa dilakukan sebagai berikut:

a. Untuk pengujian efek dari treatment (pengelompokkan bank berdasarkan kewenangan) terhadap setiap jenis kredit.

Ho : $\mathrm{a}_{1 m}=\mathrm{a}_{2 m}=\ldots=\mathrm{a}_{\mathrm{km}}=0$;

Ha : $\mathrm{a}_{1 m}{ }^{1} \mathrm{a}_{2 m}{ }^{1} \ldots{ }^{1} \mathrm{a}_{k m}{ }^{1} 0$ (setidaknya satu a $\left.{ }^{1} 0\right)$; 
dimana hipotesa nol (H0) akan diterima bila Angka Sig $>$ 0,05 dan ditolak bila sebaliknya (Angka Sig <0,05).

Penerimaan akan hipotesa nol memiliki arti bahwa perbedaan kewenangan memutus kredit yang dimiliki oleh kantor cabang bank tidak menyebabkan adanya perbedaan dalam proses persetujuan kredit pada jenis kredit tertentu secara individual, misal kredit investasi.

b. Untuk pengujian efek dari treatment (pengelompokkan bank berdasarkan kewenangan) terhadap keseluruhan kredit.

Ho : $a_{1}=a_{2}=\ldots=a_{k}=0$;

Ha: $a_{1}{ }^{1} a_{2}{ }^{1} \ldots^{\prime}{ }^{1} a_{k}{ }^{1} 0$ (setidaknya satu a $\left.{ }^{1} 0\right)$;

dimana hipotesa nol (H0) akan diterima bila Angka Sig > 0,05 dan ditolak bila sebaliknya (Angka Sig < 0,05).

Penerimaan akan hipotesa nol memiliki arti bahwa perbedaan kewenangan memutus kredit yang dimiliki oleh kantor cabang bank tidak menyebabkan adanya perbedaan dalam keseluruhan proses persetujuan kredit. Hal ini berarti pula pemberian wewenang yang lebih besar kepada Kantor Cabang Bank di daerah tidak akan mempengaruhi penyaluran kredit perbankan atau dengan kata lain tidak akan meningkatkan efektivitas pelaksanaan fungsi intermediasi perbankan di daerah.

2. Model analisa pengaruh kondisi keuangan internal perbankan serta keberadaan bentukbentuk alternatif penanaman dana lain di luar kredit terhadap penyaluran kredit perbankan di daerah.

Pembuktian pengaruh kondisi keuangan internal perbankan serta bentuk-bentuk alternatif penanaman dana lain di luar kredit terhadap penyaluran kredit perbankan dilakukan secara deskriptif dengan mempergunakan data struktur keuangan keseluruhan perbankan di masing-masing kelompok daerah paper. Dalam hal ini akan dilihat proporsi NPL's, lending capacity, loan to lending capacity, serta proporsi penanaman dana dalam bentuk lain seperti aktiva antar kantor, dan SBI.

\section{Data dan Sampling Frame}

Berdasarkan penjelasan model di atas, untuk pengumpulan data yang relevan maka pada bulan September sampai dengan Oktober 2002 telah dilakukan penyebaran kuesioner kepada seluruh kantor cabang bank di 10 provinsi yang menjadi daerah penelitian. 
Dengan disebarkannya kuesioner kepada seluruh kantor cabang bank di daerah penelitian (yang berarti populasi) maka pembentukan sampel terjadi secara otomatis dmana kuesioner yang kembali dan diisi lengkap dan valid dianggap sebagai sampel. Sementara kuesioner yang tidak kembali atau kembali dengan data yang tidak lengkap atau diperkirakan tidak valid disisihkan dan tidak menjadi sampel. Rencana dan Realisasi Sampel tersaji pada table 4.1 .

Tabel 4.1.

Rencana dan Realisasi

Jumlah KC Bank yang menjadi sampel paper

\begin{tabular}{|c|l|c|c|}
\hline No. & \multicolumn{1}{|c|}{ Daerah Paper } & $\begin{array}{c}\text { Rencana } \\
\text { (Populasi) }\end{array}$ & $\begin{array}{c}\text { Realisasi } \\
\text { sampel }\end{array}$ \\
\hline 01. & Kalimantan Selatan & 43 & 40 \\
02. & Sulawesi Utara & 43 & 17 \\
03. & Sumatera Selatan & 66 & 52 \\
04. & Kalimantan Barat & 45 & 45 \\
05. & Sulawesi Tengah & 24 & 24 \\
06. & Bali & 72 & 52 \\
07. & Jawa Barat & 295 & 76 \\
08. & NTT & 31 & 10 \\
09. & Jambi & 32 & 32 \\
10. & Lampung & 46 & 21 \\
\hline
\end{tabular}

\section{Hasil Analisa}

Sebagaimana diketahui untuk melakukan pengujian MANOVA, asumsi yang harus dipenuhi adalah matriks varians covarians dari dependent variabel yaitu persetujuan kredit pada setiap jenis kredit sama untuk setiap kelompok kantor cabang bank. Apabila variabel dependent mempunyai matriks varians covarians yang berbeda pada kelompok-kelompok kantor cabang yang ada maka analisa MANOVA tidak dapat dilanjutkan.

Pengujian asumsi homoscedasity ini dilakukan dengan melihat angka significancy pada Box's test of equality of covariance matrices yang dapat dilihat pada lampiran. Hasil pengujian pengaruh kewenangan terhadap prosentase nominal persetujuan kredit menghasilkan angka significancy sebesar 0.073. Angka significancy ini lebih besar daripada 0.05 yang berarti bahwa asumsi ada kesamaan kovarians antara variabel dependen dapat diterima (level of convidence $=95 \%$ ) dan dengan demikian model MANOVA untuk pengujian tersebut dapat dipergunakan. 


\section{Pengaruh kewenangan Kantor Cabang Bank (KCB)}

Pengujian pengaruh kewenangan terhadap prosentase nilai nominal kredit yang disetujui menghasilkan Angka significancy berdasarkan prosedur Pillai, Wilk's Lambda, Hoteling dan Roy's yang semuanya lebih kecil daripada 0.05. Dengan demikian sesuai kriteria pengujian hipotesa pada model dapat disimpulkan bahwa hipotesa nol ditolak. Hal ini selanjutnya berarti bahwa kewenangan kantor cabang bank berpengaruh kepada penyaluran kredit yang dilakukan oleh kantor cabang bank yang diukur dengan angka prosentase nilai nominal kredit yang disetujui.

Hipotesa kedua model, yaitu bahwa kewenangan kantor cabang bank berpengaruh kepada penyaluran kredit setidaknya pada salah satu jenis kredit dibuktikan dengan mempergunakan hasil perhitungan pada box test of between subjects effects. Untuk pengujian dengan mempergunakan data prosentase nilai nominal persetujuan kredit, angka significancy yang dihasilkan adalah berturut-turut sebesar $0.031,0,080$ dan 0,009, dan 0.147 untuk variabel jenis kredit investasi, modal kerja, mutiguna serta untuk kredit lainnya. Dengan demikian sesuai criteria yang telah ditetapkan maka hipotesa nol diterima hanya untuk jenis kredit modal kerja dan kredit lainnya, tetapi ditolak untuk jenis kredit investasi dan kredit multiguna. Hal ini berarti kewenangan kantor cabang bank hanya berpengaruh terhadap penyaluran kredit investasi dan kredit multiguna dan tidak berpengaruh terhadap penyaluran kredit modal kerja dan kredit lainnya.

Kredit investasi pada umumnya memiliki nilai nominal yang jauh lebih besar daripada jenis kredit modal kerja, kredit multiguna dan kredit lainnya. Berdasarkan asumsi ini maka hasil diatas menunjukkan pula bahwa kewenangan kantor cabang secara significant mempengaruhi nilai kredit yang disalurkan oleh kantor cabang bank.

Penolakan hipotesa nol untuk jenis kredit multiguna menunjukkan bahwa Kewenangan kantor cabang bank juga berpengaruh terhadap jenis kredit ini. Meskipun per individual kredit multiguna umumnya bernilai nominal relatif kecil, namun total proposal yang diajukan jauh lebih besar dibandingkan dengan jenis kredit lainnya. Sehingga dengan demikian secara keseluruhan jenis kredit ini memiliki nilai nominal yang besar dan sekaligus menegaskan bahwa kewenangan kantor cabang bank sangat mempengaruhi total penyaluran kredit di daerah.

\section{Pengaruh kondisi keuangan internal KCB terhadap penyaluran kredit}

Pengaruh kondisi keuangan internal KCB terhadap penyaluran kredit pada paper ini dicoba untuk dijelaskan dengan mempergunakan data NPLs dan penyaluran kredit yang 
dimiliki masing-masing kantor cabang bank. Rangkuman pengujian dapat dilihat pada tabel 4.2 di bawah ini:

Tabel 4.2.

Hubungan NPLs terhadap penyaluran kredit

\begin{tabular}{|c|c|c|}
\hline Daerah Penelitian & Rata Rata NPLs & $\begin{array}{c}\text { Angka Korelasi NPLs } \\
\text { dan Penyaluran Kredit }\end{array}$ \\
\hline Daerah 1 & 1.9042 & $0.336^{* *}$ \\
Daerah 2 & 2.2433 & 0.067 \\
Daerah 3 & 2.1442 & 0.072 \\
\hline
\end{tabular}

**) Correlation is significant at the 0.01 level (2-tailed). Sumber : Data primer diolah

Pada tabel terlihat bahwa secara umum tingkat NPLs dari kantor-kantor cabang bank yang ada di seluruh daerah penelitian adalah cukup rendah. Sementara itu dilihat dari angka korelasi dapat disimpulkan bahwa pada umumnya tingkat NPLs tersebut tidak memiliki hubungan yang erat dengan penyaluran kredit. Hubungan yang significant hanya terjadi di daerah penelitian 1 yang memiliki tingkat penyaluran kredit yang relatif tinggi. Hasil ini menunjukkan bahwa NPLs bukanlah faktor yang menyebabkan tingkat penyaluran kredit di daerah rendah. Rendahnya penyaluran kredit di daerah penelitian 2 dan 3 bukan disebabkan oleh NPL's yang tinggi. Rendahnya penyaluran kredit didaerah-daerah tersebut lebih disebabkan oleh faktor lainnya.

\section{Pengaruh keberadaan alternatif penanaman dana}

Pada tabel 4.3 di bawah ini dapat dilihat bahwa penggunaan dana oleh kantorkantor cabang bank di semua kelompok bank pada semua daerah penelitian adalah terutama dalam bentuk kredit. Alternatif penanaman dana lainnya seperti SBI, surat berharga dan penempatan di bank lain tidak dipergunakan secara significant, bahkan pada umumnya kantor cabang bank tidak diizinkan oleh kantor pusatnya untuk menanamkan dana secara langsung ke SBI dan surat berharga. Penanaman dana ke SBI dan surat berharga biasanya dilakukan oleh kantor pusat bank. Sementara itu penempatan dana ke bank lain hanya dilakukan secara sangat hati-hati. 
Tabel 4.3

Komposisi Penggunaan Dana

Per Kelompok Bank di Daerah Penelitian

\begin{tabular}{|c|c|c|c|c|c|c|}
\hline $\begin{array}{c}\text { Daerah } \\
\text { Penelitian }\end{array}$ & $\begin{array}{c}\text { Kelompok } \\
\text { Bank }\end{array}$ & LDR & $\begin{array}{l}\text { Rasio SBI } \\
\text { Thd DPK }\end{array}$ & $\begin{array}{c}\text { Rasio RAB } \\
\text { Thd DPK }\end{array}$ & $\begin{array}{l}\text { Rasio SB } \\
\text { Thd DPK }\end{array}$ & Total \\
\hline DAERAH 1 & $\begin{array}{l}\text { КСB1 } \\
\text { КСB2 } \\
\text { КСB3 } \\
\text { КСB4 } \\
\text { KCB5 }\end{array}$ & $\begin{array}{l}53 \% \\
66 \% \\
57 \% \\
76 \% \\
44 \%\end{array}$ & $\begin{array}{l}0 \% \\
1 \% \\
0 \% \\
0 \% \\
0 \%\end{array}$ & $\begin{array}{c}6 \% \\
25 \% \\
2 \% \\
19 \% \\
17 \%\end{array}$ & $\begin{array}{l}0 \% \\
0 \% \\
0 \% \\
0 \% \\
0 \%\end{array}$ & $\begin{array}{l}60 \% \\
92 \% \\
59 \% \\
94 \% \\
61 \%\end{array}$ \\
\hline DAERAH 2 & $\begin{array}{l}\text { КСB1 } \\
\text { КCB2 } \\
\text { КСB3 } \\
\text { KCB4 } \\
\text { KCB5 }\end{array}$ & $\begin{array}{l}46 \% \\
41 \% \\
63 \% \\
71 \% \\
44 \%\end{array}$ & $\begin{array}{l}0 \% \\
1 \% \\
0 \% \\
9 \% \\
2 \%\end{array}$ & $\begin{array}{c}0 \% \\
1 \% \\
1 \% \\
10 \% \\
0 \%\end{array}$ & $\begin{array}{l}0 \% \\
0 \% \\
0 \% \\
2 \% \\
0 \%\end{array}$ & $\begin{array}{l}46 \% \\
44 \% \\
65 \% \\
92 \% \\
46 \%\end{array}$ \\
\hline DAERAH 3 & $\begin{array}{l}\text { KCB1 } \\
\text { KCB2 } \\
\text { KCB3 } \\
\text { KCB4 } \\
\text { KCB5 }\end{array}$ & $\begin{array}{l}48 \% \\
58 \% \\
40 \% \\
66 \% \\
31 \%\end{array}$ & $\begin{array}{l}0 \% \\
0 \% \\
0 \% \\
1 \% \\
0 \%\end{array}$ & $\begin{array}{c}15 \% \\
7 \% \\
0 \% \\
9 \% \\
4 \%\end{array}$ & $\begin{array}{l}0 \% \\
0 \% \\
0 \% \\
0 \% \\
0 \%\end{array}$ & $\begin{array}{l}63 \% \\
65 \% \\
40 \% \\
75 \% \\
35 \%\end{array}$ \\
\hline
\end{tabular}

Sumber: Data Primer di olah

\section{PENUTUP}

Sehubungan dengan berbagai hasil penelitian di atas, beberapa hal yang perlu diperhatikan dalam rangka meningkatkan peran perbankan dalam pembangunan daerah adalah sebagai berikut:

1. Tetap mengupayakan agar perbankan dapat melaksanakan fungsi utamanya sebagai lembaga intermediasi dengan jalan meningkatkan pengerahan dana masyarakat di daerah dan menyalurkannya kembali dalam bentuk kredit. Namun demikian harus disadari bahwa penyaluran kredit perbankan harus dilakukan dengan prinsip kehatihatian. Peningkatan penyaluran kredit perbankan hanya dapat terjadi apabila permintaan kredit yang disertai kelayakan usaha di daerah cukup tinggi.

2. Menimbang bahwa permintaan kredit di daerah dipengaruhi oleh iklim dunia usaha di daerah secara keseluruhan, maka dalam rangka peningkatan penyaluran kredit perbankan peran pemerintah daerah sangat diharapkan. Pemerintah daerah diharapkan 
mampu meningkatkan jaminan keamanan dan memberikan kemudahan birokrasi yang pada pada gilirannya akan menciptakan iklim dunia usaha yang kondusif. Pada akhirnya iklim dunia usaha yang kondusif diharapkan dapat meningkatkan aktivitas usaha yang berarti meningkatkan investasi, sekaligus akan meningkatkan permintaan kredit perbankan.

3. Meskipun desentralisasi perbankan dalam bentuk perubahan sistem dari branch banking system ke unit banking system diperkirakan akan cukup mempengaruhi tingkat penyaluran kredit perbankan di daerah, namun disarankan untuk tidak diterapkan secara tergesagesa. Penerapan desentralisasi perbankan hanya dengan tujuan meningkatkan penyaluran kredit perbankan di daerah dikhawatirkan akan mendorong perbankan di daerah meninggalkan prinsip kehati-hatian yang pada gilirannya akan membahayakan industri perbankan secara keseluruhan. Sehubungan dengan hal ini, usulan penerapan desentralisasi perbankan sebaiknya ditangguhkan agar tidak menjadi distorsi dari upaya penyehatan perbankan nasional yang saat ini tengah berlangsung.

\section{DAFTAR PUSTAKA}

Armstrong, H.W., and J. Taylor, “Regional Economics and Policy”, Blackwell, London, 1985.

Gultom, Miranda. S., "Pemulihan Fungsi Intermediasi Perbankan: Upaya Revitalisasi Ekonomi", Diskusi Panel "Pemulihan Kembali Funsi Intermediasi Perbankan Sebagai Lembaga Intermediasi di Bidang Keuangan”, tgl 14 Februari 2002, Jakarta.

Santoso, Singgih, "SPSS - Statistik Multivariat", Elex Media Computindo, Jakarta, 2002

Santoso, Singgih, "SPSS - Statistik Parametrik", Elex Media Computindo, Jakarta, 2002 , Undang Undang Republik Indonesia No.23 tahun 1999 tentang Bank Indonesia. ,Undang Undang Republik Indonesia No.7 tahun 1992 tentang Perbankan. , Undang Undang Republik Indonesia No.10 tahun 1998 tentang perubahan atas UU RI No. 7 tahun 1992 tentang Perbankan.

“Laporan Tahunan 2001", Bank Indonesia, Jakarta 2002 